\title{
Pseudopsis monica sp. nov. from the western Andes, Peru, with a key to the South American species of Pseudopsis Newman (Coleoptera, Staphylinidae, Pseudopsinae) ${ }^{1}$
}

\author{
Angélico Asenjo² \& Cibele S. Ribeiro-Costa ${ }^{2,3}$
}

${ }^{1}$ Contribution number 1799 of the Departamento de Zoologia, Universidade Federal do Paraná, Brazil.
${ }^{2}$ Laboratório de Sistemática e Bioecologia de Coleoptera (Insecta), Departamento de Zoologia, Universidade Federal do Paraná, Caixa Postal 19020,
81531-980 Curitiba-PR, Brazil. pukara8@yahoo.com; stra@ufpr.br.
${ }^{3}$ CNPq fellowship. ABSTRACT. Pseudopsis monica sp. nov. from the western Andes, Peru, with a key to the South American species of Pseudopsis
Newman (Coleoptera, Staphylinidae, Pseudopsinae). Pseudopsis Newman, 1834 is a genus of Pseudopsinae with about 46 species
distributed worldwide, five of which have been reported for South America. In this paper P. monica sp. nov. is described and
illustrated based on specimens collected in Lima, Peru. A key to South American species of Pseudopsis and a catalog are also
provided.

KEYWORDS. Catalog; Neotropical region; new species; rove beetles.

RESUMO. Pseudopsis monica sp. nov. do oeste dos Andes, Peru, com chave para as espécies da America do Sul de Pseudopsis Newman (Coleoptera: Staphylinidae, Pseudopsinae). Pseudopsis Newman, 1834 é um gênero de Pseudopsinae com cerca de 46 espécies distribuídas no mundo, destas cinco são registradas para a América do Sul. Nesta contribuição P. monica sp. nov. é descrita com base em exemplares coletados em Lima, Peru. Uma chave para as espécies de Pseudopsis da América do Sul e um catálogo são fornecidos.

PALAVRAS-CHAVE. Catálogo; espécie nova; estafilinídeo; região Neotropical.

Pseudopsis Newman, 1834 is the largest of the four genera of the subfamily Pseudopsinae, with about 46 species distributed worldwide (Herman 2001; Zerche 2003). Herman's contribution (1975) was the most relevant to study of genus Pseudopsis to date; he revised 28 species and performed a cladistic analysis based on 35 morphological characters of adults. Six groups of species were established in his paper, five of them composed of a single species and each from different regions: the adustipennis group ( $P$. adustipennis, Fairmaire \& Germain 1861; Argentina, Chile), montoraria group (P. montoraria Herman, 1975; Canada, USA), obliterata group (P. obliterata LeConte, 1879; USA), minuta group (P. minuta Fall, 1901; USA), arrowi group ( $P$. arrowi Bernhauer, 1939; New Zealand). The sulcata group or sulcata complex comprises 23 species distributed in the Old and New World.

Fairmaire \& Germain (1861) described the first species for South America, P. adustipennis (Chile). Fauvel (1865) described $P$. columbica (Venezuela), later synonymized with P. grossa Herman, 1975 (Colombia) by Zerche (1992). P. wygodzinskyi (Ecuador) was described by Herman (1975) when he revised Pseudopsinae. Posteriorly, Zerche (1992) described $P$. campbelli (Ecuador) and, more recently the same author Zerche (2003), described P. ecuadorensis (Ecuador). At present, there are five species known from South America.

In 2005 staphylinid beetles were collected in the Chillón River Valley, Lima, Peru, in order to investigate the altitudinal distribution of species. The material included the first specimen of Creophilus maxillosus (Linnaeus, 1758) (Staphylininae) for Peru (Asenjo \& Clarke 2007) and a new species of Pseudopsis described here. The only record in the literature of Pseudopsis from Peru is P. columbica (Fauvel 1865). Solsky (1875) reported the same species from Peru, but we consider this record doubtful because there are no new records of the species in Peru since 1875 . Hence, the species here described might be considered as the first record of Pseudopsis for Peru.

\section{MATERIAL AND METHODS}

The followings acronyms were used: AMNH, American Museum of Natural History, New York, USA; CNC, Canadian National Collection of Insects, Ottawa, Canada; DEI, Deutshes Entomologisches Institut Eberswalde, Eberswalde Finow, Germany; DZUP, Coleção de Entomologia Pe. J.S. Moure, Departamento de Zoologia, Universidade Federal do Paraná, Curitiba, Brazil; MUSM, Museo de Historia Natural de la Universidad San Marcos, Lima, Peru; MZLU, Zoological Museum Lund University, Lund, Sweden.

For the present paper, it was necessary to examine the holotype of Pseudopsis campbelli Zerche, 1992, deposited in the CNC.

The specimens of the new species described here are deposited in the entomological collection of the MUSM and DZUP. 
To study internal structures, dried specimens were boiled in water for five minutes, and then left in $10 \% \mathrm{KOH}$ over night. The dissection was carried out under a Carl Zeiss Stemi SV6 stereoscopic microscope and the drawings made with the same equipment.

Images were captured with computer software IM 50 (Image Manager) and combined using the image processing software Auto-Montage Pro (Syncroscopy).

The micrographs were taken from specimens not metalized using the Jeol JSM-6360LV scanning electron microscope, at the Centro de Microscopia Eletrônica (CME) of the Universidade Federal do Paraná (UFPR).

Measurements were taken in "mm" using a micrometer ocular in the Carl Zeiss - Stemi SV6 stereomicroscope.

Terminology adopted in this paper follows Herman (1975).

The following abbreviations were used: BL, body length (from anterior margin of head to posterior margin of tergite VIII); BW, body width (maximum width of elytra); EL, elytral length (from apex of scutellum to apex of elytron); EW, elytral width (maximum); HW, head width (maximum); HL, head length (maximum); PL, pronotum length (maximum); PW, pronotum width (maximum).

\section{Pseudopsis monica Asenjo \& Ribeiro-Costa sp. nov.} (Figs. 1-14)

Type material. Holotype, male, labeled as follows: "PERU: LI, Valle Río Chillón, 3km E Canta, 2964m, 11²8’28.2”S, 76³7’1.3”W, 11.vi.2006, under cowpie, A. Asenjo." "Holotype Pseudopsis monica Asenjo \& Ribeiro-Costa, Desig. Asenjo \& Ribeiro-Costa, 2010” (MUSM). Paratypes, 5 females with same data as holotype, and with label "Paratype Pseudopsis monica Asenjo \& Ribeiro-Costa, Desig. Asenjo \& Ribeiro-Costa, 2010” (4 MUSM, 1 DZUP).

Description. Holotype male. BL: $3.34 \mathrm{~mm}$; BW: $0.94 \mathrm{~mm}$. Body dark brown; trocanter, apex of femora, tibiae and tarsi, light brown. Antennae light brown except scape brownish. Labium and maxillae light brown. Head coarsely and densely punctated and abdomen with bicolored clubbed setae, basally dark brown, medioapically yellowish. Abdominal tergites and sternites with small yellowish hairs.

Body moderately flattened dorsoventrally. Head (Fig. 3) almost square, slightly wider than long (HW: $0.51 \mathrm{~mm}$; HL: $0.45 \mathrm{~mm}$ ), lateral margin carinate, arched, with the apical region curved outside. Dorsum coarsely and densely punctuate, some punctures anastomosing and forming irregular short, carinules; one median longer straight carinula interrupted medially and two other straight carinula lateral posteriorly, gently divergent at base; moderately deep depression between median carinula and external margin of head. Clypeal, supraorbital, lateroposterior, and medioposterior clubbed setae present (Fig. 3); postorbital seta absent. Subocular carina start near base of maxilla extending below eyes to the lateral region of head.

Mandibles asymmetrical (Fig. 7) with basal molar region; right mandible tridentate, apical denticle smooth, median denticle acute at apex, basal denticle rounded apically; left mandible tridentate, apical denticle smooth, median and basal denticles rounded at apex.

Pronotum wider than long (PL: $0.63 \mathrm{~mm}$; PW: $0.84 \mathrm{~mm}$ ), anterior margin truncate, lateral margins arched and bordered with small punctures, posterior margin with rounded borders. Lateral carina complete reaching and surrounding the anterior angles. Surface coarsely and densely punctuate, some punctures anastomosing and forming irregular short, carinules; one median straight and complete carinula. Two median and two lateral strong longitudinal carinae; depressed irregular areas near posterior border among carinae (fig. 4). Prohypomeron with punctures moderately coarse, dense; dorsal edge with a row of small punctures, each with seta. Surface of procoxae to fit the femur with irregular, small grooves, delimited by carina at the medial region. Prosternal process and mesosternum carinate. Scutellum heart-like, rounded apex, with longitudinal carinae not reaching apex. Elytron longer than wide (EL: $0.65 \mathrm{~mm}$; EW: $0.49 \mathrm{~mm}$ ), punctures moderately dense, coarse, shorter than those of pronotum; carinules absent. Four strong, well developed longitudinal carinae. Humeral carina (HC) at lateral margin, bordered with small punctures, gently curved posteriorly and anteriorly extending to meet sutural carina (SC). Sutural carina (SC) and discal carina (DC) both gently curved at the apex, not reaching the posterior margin of elytron. Epipleural carina joining humeral carina (HC) and discal carina (DC) at the humeral angle (Fig. 5). Pubescence short, yellowish.

Abdomen yellowish pubescent; setae posteriorly directed. Terga, paratergites, and sternites with clubbed setae (Figs. 1-2, 6). Terga III to VI each with four clubbed setae on posterior margin; paratergites III to VI each with one clubbed setae on posterior margin; tergum VII with one pair of clubbed seta in middle region; sterna IV to VII each with clubbed setae on posterior lateral margin. Sternite VII without median depression. Posterior margin of sternum VIII of male straight (Fig. 9). Sternum IX (Figs. 10-11) of male with posterior margin slightly emarginate, medially straight; with short and strong spinelike setae; lateroapical region with spinelike; apical region with two long, moderately stout setae each lateral of midline. Tergal elements of segment IX of male with two pairs of slender setae of different lengths, anteriorly directed struts on anterior margin; lateral strut about half length of medial strut. Aedeagus asymmetrical (Fig. 12). Parameres (Fig. 13) in lateral view gradually deflected ventrally and in ventral view nearly straight; base of paramere fused to median lobe, forming elliptical inner margin; apex of paramere not reaching apex of median lobe, with four unpigmented stout spines setae; apical seta long, reaching apex of median lobe. Median lobe broad, membranous except for apex with sclerotized plates laterally; the apical third gradually tapered, ending in round pointed apex; inner margin V-shaped, vertex rounded; area around basal orifice membranous. Internal sac, in repose (Fig. 14), broad, longer than median lobe; in lateral aspect with numerous stout, imbricate spines and numerous small spines not arranged in rows.

Distribution and Habitat

Pseudopsis monica sp. nov. is known only from near Canta, Lima, Peru, where it was collected under cow pies. 

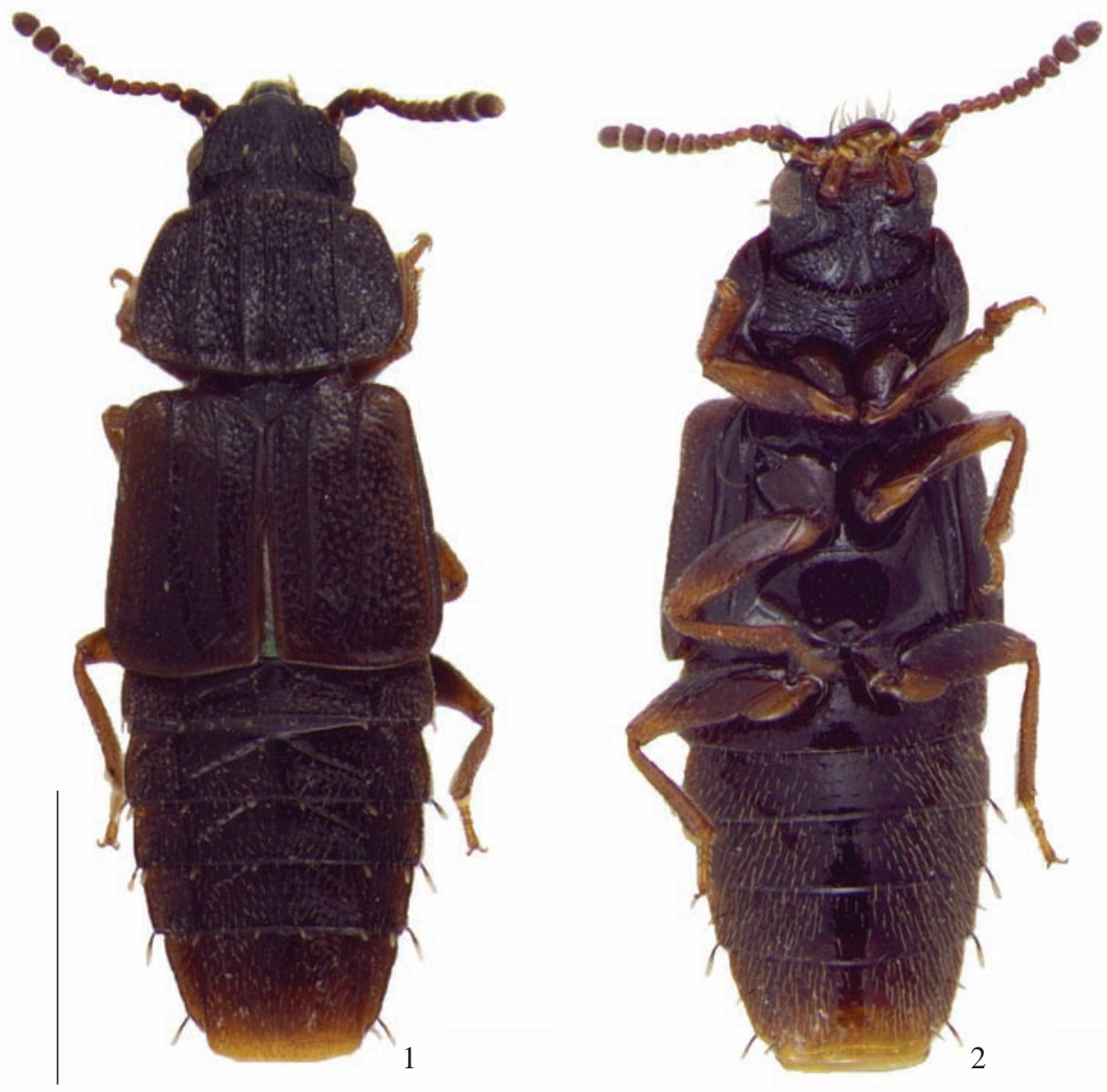

Figs. 1-2. Pseudopsis monica sp. nov.; holotype male. 1. Dorsal view; 2. Ventral view. Scale bar $1.0 \mathrm{~mm}$.

\section{Etymology}

It is a great pleasure to dedicate this species to Mónica Higuera Díaz, a brilliant lepidopterist from Colombia. The specific name "monica" is a noun in apposition, gender feminine.

Taxonomic discussion

The genus Pseudopsis is easily differentiated from the other Pseudopsinae by the following characters (Newton 1982): last segment of maxillary palp less than a third as wide as penultimate segment; procoxal fissure widely open, trochantin well exposed; abdominal terga with basolateral ridges, tergum VIII with comb on posterior margin; abdominal sterna II and III without intercoxal carina.

Pseudopsis monica sp. nov. shares all of the above characters and belongs to the sulcata group, together with 23 other species (Herman 1975). The sulcata group is defined mainly by the strongly carinate head, pronotum and elytra (Figs. 3-5); clubbed cephalic and abdominal setae (Figs. 3, 6); presence of parameres (Figs. 12, 13); fused coxites and absence of the stylus in the female; and absence of the basal sclerite of the median lobe in the male (Figs. 12, 13).

$P$. monica sp. nov. shares characters of the aedeagus with the Ecuadorian species $P$. campbelli and $P$. wygodzinskyi. $P$. monica sp. nov. shares with $P$. campbelli the apex of parameres not reaching the apex of median lobe, and the median lobe with a pointed round apex (Fig. 12) (Zerche 1992; fig. 12). $P$. monica sp. nov. can be differentiated from P. campbelli by the internal sac, in repose, longer than median lobe and stout spines not arranged in rows (Fig. 14) (Zerche 1992; fig. 12).

$P$. monica sp. nov. shares with $P$. wygodzinskyi the internal sac in repose longer than the median lobe and stout spines not arranged in rows; $P$. monica sp. nov. has the internal sac with imbricated spines (Fig. 14) (Herman 1975; fig. 136). $P$. monica sp. nov. can be separated from $P$. wygodzinskyi because the apex of parameres does not reach the apex of the median lobe (Fig. 12) (Herman 1975; fig. 135).

$P$. columbica ( $=P$. grossa) was recorded for Peru but the record is old and in our opinion doubtful. Nevertheless, $P$. monica sp. nov. is separated from $P$. columbica by the presence of the attenuate median lobe in the male (Herman 1975; 130) (Fig. 12), the internal sac longer than the median lobes and the presence of moderately stout spines not arranged in rows (Herman 1975; 131) (Fig. 14).

Key to South American Pseudopsis species

1. Pronotum with four well-developed longitudinal costae (Herman 1975; fig. 179); sutural carina (SC) of elytra poorly developed (Herman 1975; fig. 182). Venezuela 

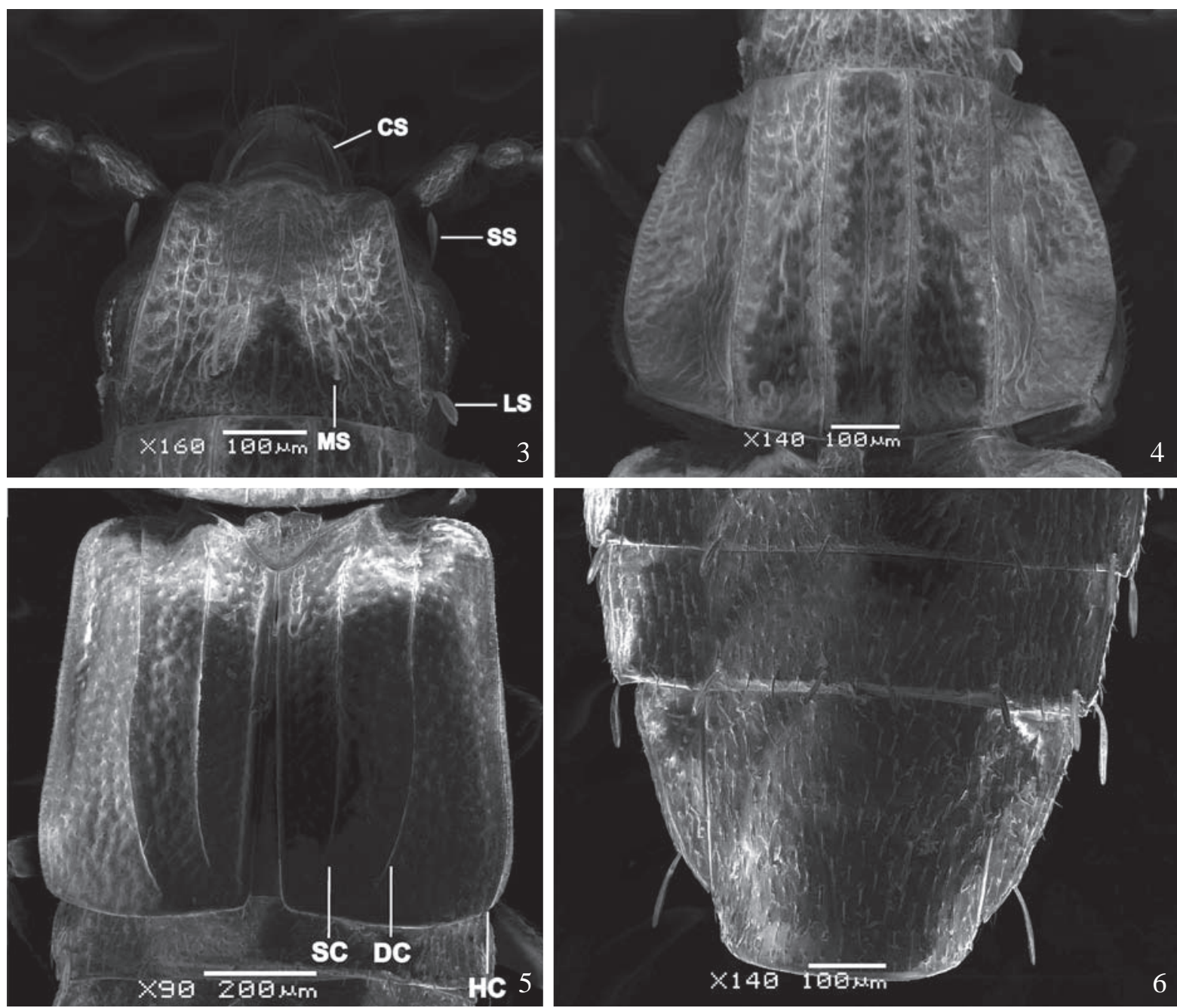

Figs. 3-6. Pseudopsis monica sp. nov.; holotype male. 3. Head, dorsal view; 4. Protorax, dorsal view; 5. Elytra, dorsal view; 6. Terga IV-VII, dorsal view. CS, clypeal seta; DC, Discal carina; HC, Humeral carina; LS, lateroposterior seta; MS, medioposterior seta; SC, Sutural carina; SS, supraorbital seta.

(Register doubtful), Argentina, Chile

P. adustipennis Fairmaire \& Germain, 1861

Pronotum with four well-developed longitudinal carinae (Herman 1975; figs. 1, 142) (Fig. 4), sutural carina of elytra well-developed (Herman 1975; fig. 1) (Fig. 5). 2

2. Apex of parameres reaching apex of median lobe or slightly longer (Herman 1975; fig. 135) (Zerche 2003; fig. 4) 3

Apex of parameres not reaching apex of median lobe (Herman 1975; fig. 130) (Zerche 1992; fig. 12) (Figs. $12,13)$

3. Parameres asymmetrical. Apex of parameres slightly longer than median lobe. Internal sac, in repose, with one row of moderately stout spines (Zerche 2003; fig. 4). Ecuador P. ecuadorensis Zerche, 2003

Parameres symetrical. Apex of parameres reaching apex of median lobe. Internal sac in repose with moderately stout spines not arranged in rows (Herman 1975; figs. 135, 136). Ecuador ...... P. wygodzinskyi Herman, 1975
4. Apex of median lobe not narrowly attenuate. Internal sac, in repose, with stout spines (Herman 1975; figs. 130, 131). Colombia, Venezuela, Peru (Register doubtful)... P. columbica Fauvel, 1865

Apex of median lobe narrowly attenuate. Internal sac, in repose, with stout spines (Zerche 1992; fig. 12) (Figs. $12,14)$ 5

5. Internal sac, in repose, not longer than median lobe and with two rows of moderately stout spines (Zerche 1992; fig. 12). Ecuador P. campbelli Zerche, 1992

Internal sac, in repose, longer than median lobe and curved at base, and with imbricated stout spines not arranged in rows (Fig. 14). Peru

P. monica Asenjo \& Ribeiro-Costa sp. nov.

Catalog of Pseudopsis species from South America

Pseudopsis adustipennis Fairmaire \& Germain, 1861: 455

Holotype: Museum?, sex?, Chile: Chiloe, in decayed wood (Herman 1975). 


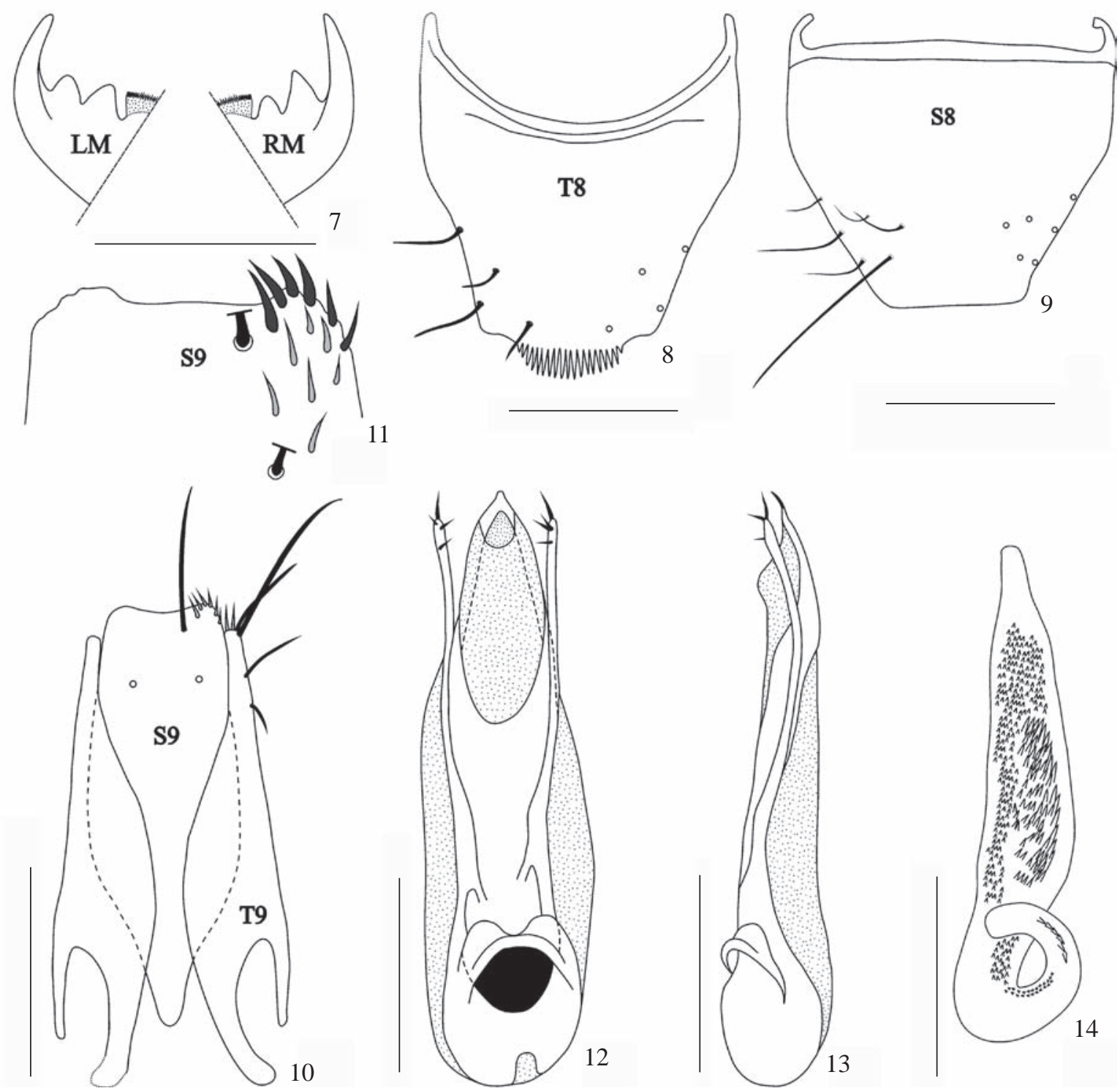

Figs. 7-14. Pseudopsis monica sp. nov.; Paratype female 7, holotype male 8-14. 7. Mandible left and right, dorsal view; 8. Tergum VIII; 9. Sternum VIII; 10. Tergum IX \& sternum IX; 11. Apex of sternum IX; 12. Aedeagus, ventral view ; 13. Aedeagus, lateral view; 14. Internal sac, inverted, lateral view. LM, left mandible; RM, right mandible; T8, tergum VIII; S8, sternum VIII; S9, sternum IX; T9, tergum IX. Scale bars 0.25 mm.

Distribution:ARGENTINA:Neuquén.CHILE:Coquimbo, De los Lagos-Chiloé-Ancud, Aisén. VENEZUELA: [Register doubtful]. (Blackwelder 1944: 101, Coiffait \& Saiz 1968: 459, Herman 1975: 308, Herman 2001: 1998).

Pseudopsis campbelli Zerche, 1992: 291

Holotype: CNC, male, Ecuador: Napo: Baeze, 6800 ft., 23.iv.1982. H. Frania \& F. Sperling, ex rotting leaves, canopy of fallen tree (Zerche 1992).

Distribution: ECUADOR: Napo. (Zerche 1992: 291, Herman 2001: 1998)

Pseudopsis columbica Fauvel, 1865: 3

Synonym: Pseudopsis grossa Herman, 1975: 294 (Zerche 1988: 154)

Holotype: Museum?, female, Venezuela: Caracas (Herman 1975)
Distribution: COLOMBIA: Valle del Cauca. PERU: [Register doubtful]. VENEZUELA: Distrito Federal. (Blackwelder 1944: 101, Solsky 1875: 25, Herman 1975: 296, Zerche 1992: 292, Herman 2001: 1999, Asenjo 2004: 60, Newton et al. 2005: 40)

\section{Pseudopsis ecuadorensis Zerche, 2003: 166}

Holotype: MZLU, male, Ecuador: Napo, W of Papallacta [ca. $0^{\circ} 22^{\prime} \mathrm{S} 78^{\circ} 10^{\prime} \mathrm{W}$ ], $4000 \mathrm{~m}$, Yellow pan trap, 10-23.ii.1983, leg. L.Huggert (Zerche 2003).

Distribution: ECUADOR: Napo. (Zerche 2003: 166)

Pseudopsis monica Asenjo \& Ribeiro-Costa sp. nov.

Holotype: MUSM, male, PERU: LI, Valle Río Chillón, 3km E Canta, 2964m, 11²8'28.2”S, 76³7’1.3”W, 11.vi.2006, under cowpie, A. Asenjo.

Distribution: PERU: Lima. 
Pseudopsis wygodzinskyi Herman, 1975: 294

Holotype: AMNH, male, Ecuador: Cotopaxi: NW slope of Mt. Cotopaxi, 3500 meters, July 26-August 5, 1969, P. and B. Wygodzinsky (Herman 1975).

Distribution: ECUADOR: Cotopaxi. (Herman 1975: 294, Herman 2001: 2003)

Acknowledgements. We would like to thank Edilson Caron (UFPR), Lee Herman (AMNH), Pedro Lozada (MUSM), and Lothar Zerche (DEI) for providing literature; Anthony Davies (CNC) for the loan of the type of Pseudopsis campbelli; and Pino Gaviño (UNMSM), Rafael Alvis (UNMSM), and the Laboratorio de Fisiología y Reproducción Animal de la Universidad Nacional Mayor de San Marcos (UNMSM) for permission to use their optic equipment. We thank to Nigel Pitman for the suggestions on manuscript. We thank Fernando Jose Fontana-Tionteke of the Centro de Microscopia Eletrônica (CME/UFPR) for the micrographs and the Conselho Nacional de Desenvolvimento Científico e Tecnológico (CNPq) for providing scholarships to the authors.

\section{REFERENCES}

Asenjo, A. 2004. Lista preliminar de las especies de Staphylinidae (Coleoptera) registradas para Perú. Revista Peruana de Entomología 44: $55-64$

Asenjo, A. \& D. J. Clarke. 2007. First record of Creophilus maxillosus (Linnaeus, 1758) (Staphylinidae) for Peru. The Coleopterists Bulletin 61: 551.

Blackwelder, R. E. 1944. Checklist of the Coleopterous Insects of Mexico, Central America, The West Indies, and South America. Part 1. United States National Museum Bulletin 185: 1-188.
Coiffait, H. \& F. Saiz. 1968. Les Staphylinidae (sensu lato) du Chile, p. 339-468. In: C. Deboutteville \& E. Rapoport (eds.). Biologie de l'Amérique Australe. Vol. 4. Documents Biogéographiques et Écologiques. Paris, Centre National de la Recherche Scientifique, i+472 p.

Fauvel, A. 1865. Études sur les Staphylinides de l’Amérique centrale principalement du Mexique. Notices Entomologiques 3: 1-18.

Fairmaire, L. \& P. Germain. 1861. Révision des Coléoptères du Chili. Annales de la Société Entomologique de France 4: 405-456.

Herman, L. H. 1975. Revision and phylogeny of the monogeneric subfamily Pseudopsinae for the world (Staphylinidae, Coleoptera). Bulletin of the American Museum of Natural History 155: 241-318.

Herman, L. H. 2001. Catalog of the Staphylinidae (Insecta: Coleoptera). 1758 to the end of the second millennium. IV. Staphylinine Group (Part 1). Bulletin of the American Museum of Natural History 265: 1807-2440.

Newman, E. 1834. Entomological notes. The Entomological Magazine 2: 200-205, 313-315.

Newton, A. F. 1982. Redefinition, revised phylogeny, and relationships of Pseudopsinae (Coleoptera, staphylinidae). American Museum of Natural History 2743: 1-13.

Newton, A. F.; C. Gutiérrez-Chacón \& D. S. Chandler. 2005. Checklist of the Staphylinidae (Coleoptera) of Colombia. Biota Colombiana 6: 1-72.

Solsky, S. M. 1875. Matériaux pour l'entomographie de l'Amérique du Sud. Staphilinides recueillis par MM. C. Jelsky et le Baron de Nolcken dans le Pérou el la Nouvelle Grenade. Article III. Horae Societatis Entomologicae Rossicae 11: 3-26.

Zerche, L. 1992. Zur Taxonomie und Verbreitung der Gattung Pseudopsis Newman, 1834 (Coleoptera, Staphylinidae, Pseudopsinae). Beiträge zur Entomologie 42: 279-292.

Zerche, L. 2003. Pseudopsis-Studien 6: Neue Arten und neue Funde aus der Palaearktis, der Nearktis und der Neotropis (Insecta: Coleoptera: Staphylinidae: Pseudopsinae). Entomologische Abhandlungen (Dresden) 60: 161-169. 